\title{
Çanakkale Cephesinde Hava Harekatı ve Safhaları
}

\author{
Soner ORAN
}

\section{Özet}

Birinci Dünya Savaşı'nda Osmanlı Devleti'nin, Çanakkale Boğazı'nı ele geçirmeye ve İstanbul'u işgal etmeye yönelik İngiliz-Fransız ortak harekatına karşı yürüttüğ̈̈ ve Türk Askeri Tarihi'nin en önemli savunma savaşlarından biri olan Çanakkale Savaşları'nda Hava Kuvvetleri her ne kadar çok incelenmese de, zaferin kazanılmasında önemli bir rol üstlenmiştir. Bu kapsamda çeşitli olanaksızlıklara rağmen, özellikle Almanya'nın desteğiyle gelişme aşamasında olan Türk Hava Kuvvetleri'nin, ilk ve önemli başarılarından biri olan Çanakkale Hava Harekatı'nın incelenmesi gerekli olmuştur.

Anahtar Kelimeler: Türk Hava Kuvvetleri, Çanakkale Boğazı

\section{The Air Operations and Phases of the Dardanelles Campaign}

\section{Abstract}

Even though it has not been examined well before, the Dardanelles Air Wars performed an important role to win a victory in the Dardanelles Wars which is accepted as most important Turkish defense war against French-British joint operation in order to occupy Istanbul and Dardanelles Bosporus in the First World War. For this reason explaining the Dardanelles Air Wars which are accepted as one of the most important successes of Turkish Air Forces in developing phase by means of German assistance has came into prominence.

Key Words: Turkish Air Forces, Dardanelles Bosporus.

\footnotetext{
*Ankara Üniversitesi Türk İnk1lâp Tarihi Enstitüsü Doktora Öğrencisi
} 


\section{Giriş}

Yaklaşık 195 bin askerin kayıp** 57 bin askerin şehit düştüğü Çanakkale Cephesi; Birinci Dünya Savaşı’nın tüm şiddetiyle devam ettiği sırada, savaşın seyrini değiştirerek önemli sonuçlar doğurması bir yana, askeri havacılık açısından da birçok ilkin yaşanmasına neden olmuştur. 1911 yılında temelleri atılan ve o dönemde kişisel çabalarla geliştirilmeye çalışılan Türk Hava Kuvvetleri, Yeşilköy'de Kara Tayyare Mektebi ve Deniz Tayyare Mektebleri'nin kurulmasının ardından havacı personel yetiştirmeye de başlamış ve Balkan Savaşları ardından en önemli zaferini Çanakkale Cephesi'nde kazanmıştır. Bu cephede her ne kadar tarafların havada karşılaşması sınırlı olsa da, gerçekleşen hava muharebelerinde üstünlük sağlanmıştır.

Çanakkale Cephesinde Türk ve Müttefik Hava Kuvvetleri genel olarak keşif ve bombardıman amaçlı olarak görev almışlardır. Bu açıdan hava harekatları, deniz ve kara savaşları öncesinde başlamış ve düşmanın kesin olarak çekildiği Ocak 1916 sonrasında da yoğun olarak devam etmiştir. Yaklaşık sekiz buçuk ay süren deniz ve kara savaşları ile birlikte süregelen hava savaşlarında, askeri havacılık alanında birçok ilkler de yaşanmış; sonuç olarak Müttefiklere karş1 kayda değer bir üstünlük sağlanmıştır.

\section{Çanakkale Cephesinin Açılması ve Müttefiklerin Çanakkale Boğazına Saldırışı}

Asya ve Avrupa kıtaları ve Marmara-Ege Denizleri arasında kuzeydoğu ve güneybatı yönünde doğal bir suyolu olarak uzanan Çanakkale Boğazı; uzunluğu $62 \mathrm{~km}$, en dar yeri ortada $1,3 \mathrm{~km}$, en derin yeri Çanakkale Kenti karşısında 100 metre ve ortalama derinliği 50-60 metre olan önemli bir boğazdır. Yabancı dilde Dardaneller Boğazı ve Osmanlı kaynaklarında Akdeniz ya da Hisar Boğazı olarak isimlendirilen boğaz Çanakkale Deniz Savaşları'nın alanı olmuştur. ${ }^{1}$

Şüphesiz boğazın en önemli özelliği, stratejik ve ekonomik önemine paralel olarak Karadeniz ve Akdeniz devletlerinin kısa yoldan ilişkiye geçmesine olanak vermesidir. Bu nedenle Birinci Dünya Savaşı'nda da boğazlara sahip olmak Akdeniz ve Karadeniz'de harekatı başarıyla

${ }^{* *}$ Genelkurmay Başkanlığı Askeri Tarih Araştırmaları Strateji Etüdler Daire Başkanlığı (ATASE) tarafından yürütülen araştırmada cephede şehit düşen 55 bin 801 kişinin ismi tek tek belirlenmiş, Genelkurmay Başkanlığı tarafından "kayıp" ifadesinin; hastalık, esirlik, kaybolan, kaçan, sakat kalan, yaralanan, sonradan savaşamayacak duruma düşenleri kapsadığ 1 belirtilmiștir.

${ }^{1}$ M. Orhan Bayrak, Çanakkale Savaşları, Bir Harf Yayınları, İstanbul, 2005, s. 15. 
sürdürebilmek için şart olmuştur. Bu nedenle Müttefik Harekatının birincil amacı Boğazların deniz yoluyla geçilmesi olmuştur. Gerçekte Çanakkale Boğazı'nda deniz gelgiti olmamasına rağmen su yüzeyinde Marmara'dan Ege'ye doğru saatte 34 mili bulan bir akıntı vardır. Boğaz bir hayli uzun olması, yer yer daralıp genişlemesi, sürekli kıvrımlarla kolay geçilebilecek bir konumda değildir. ${ }^{2}$

Boğazın en geniş yeri Erenköy Koyu ile Tengerdere ağzı arası çizgisidir. Eski Hisarlık Burnu'ndan sonra Boğaz batıya doğru bir kıvrım yaparak, Morto Limanı'nı oluşturmaktadır. Karanlık Liman ve Morto Limanı'ndan sonra Boğaz darlaşmakta, Kumkale ve Seddülbahir çizgisinde son bularak Ege Denizi'ne açılmaktadır. Bunun yanı sıra Kumkale ve Seddülbahir bölgesine boğazın girişi de denilmektedir. ${ }^{3}$

Bölgede amfibi hareketlerine en elverişli kıyılar üç ayrı kesimde toplanmıştır. Bunlardan ilki Gelibolu Kavak Suyu ağzı ve Bakla Koyu kıyılarıdır. Fakat bu kesimin çıkarma tekniği açısından avantajına rağmen müstahkem mevki bölgesine uzaklığı, aradaki arazi yapısının dar ve çok engebeli oluşu ve Trakya'daki ana yığınak kuvvetleriyle Çanakkale'yi savunan kuvvetler arasında sıkışıp ezilmesi gibi taktiksel ve stratejik sakıncaları vardır. Bununla beraber çıkarma harekatını destekleyecek donanmanın ileri üsleri de uzaktır. ${ }^{4}$

Çanakkale Boğazı'nın Müttefik güçlerince deniz yoluyla geçilmesinin kesin olarak kararlaştııılmasından sonra, taraflar gerçekleştirilen saldırı öncesinde ve sonrasinda hava gücünden özellikle keşif amacıyla faydalanmışlardır. $\mathrm{Bu}$ dönemde İngiliz ve Fransız Hava Güçleri'yle karşılaştırıldığında daha yetersiz olan Türk Hava Kuvvetleri, buna karşın düşman güçlerinden çok daha başarılı şekilde keşif çalışmaları yürütmüştür.

Osmanlı İmparatorluğu'nun savaşa dahil olmasının ardından, Müttefik Kuvvetler savaş başlamadan planladıkları gibi Çanakkale'ye gelmişler, Ekim 1914'ten itibaren de Boğaz'da dış ve orta savunma tabyalarını tahrip ederek bölgeye önemli oranda kuvvet yığmaya başlamışlardı. Balkan Savaşları'ndan yeni çıkmış Yeşilköy Uçuş Okulu'nda askeri göreve uygun uçaklar bulunmamasına rağmen, Çanakkale'nin zorlanacağının anlaşılması üzerine ilk aşamada Osmanlı Ordusu bombardıman başlamadan önce

\footnotetext{
${ }^{2}$ İbrahim Artuç, 1915 Çanakkale Savaşı, Kastaş Yayınları, İstanbul, 2004, s. 53.

${ }^{3}$ Birinci Dünya Harbi'nde Türk Harbi: Çanakkale Cephesi Harekatı ( Haziran 1914-24 Nisan 1915), V. Cilt, I. Kitap, Genelkurmay Basımevi, Ankara,1993, s.16.

${ }^{4}$ Birinci Dünya Harbinde Çanakkale Cephesi, V. Cilt, 2. Kitap, Genelkurmay Harp Tarihi Başkanlığı Harp Tarihi Yayınları, Seri No. 3, Genelkurmay Basımevi, Ankara, 1978, s.7.
} 
Boğazın gözetlenmesi amacıyla Çanakkale'ye uçak göndermiştir. İngiliz filosu öncelikle Limni adasındaki Mondros limanını işgal etmiş ve burayı üs olarak kullanmaya başlamıştı. Yapılan ilk hava keşfi sonucunda İngiliz deniz kuvvetlerinin boğazın dışında görüldüğü tespit edilmişti.

Seferberliğin başlangıcında ikisi Yeşilköy'den İzmir'e ve biri Çanakkale'ye olmak üzere üç uçak sevk edilmiş, ancak çeşitli arızalar nedeniyle geri çağrılmışlardır. ${ }^{5}$ Bunun ardından Çanakkale Mevkii Müstahkem Komutanlığı emrine bu kez bir adet deniz Nieuport uçağ 1 verilmiş ve Fazıl'ın idaresindeki bu uçak 17 Ağustos 1914'te Çanakkale'ye varmıştır. Ancak kara uçağı beklendiğinden, uçak sahile bağlanarak deniz kenarında acilen bir hangar inşasına geçilmiştir. Aynı gün Müttefikler, Short uçağ 1 ile, bir nakliye gemisine ve insan dolu bir sala taarruz etmişlerdi. Ancak bu dönemde uçaklarla yapılan bu tip taarruzlar seyrek olmuştur. Bunun nedeni, 250 beygir gücünde olan motorla teçhiz edilmiş bir uçağın daha farklı ve ağır yük taşıyabilmesi için uygun hava koşulları gerekiyor olmasıydı. 5 Eylül'de Fazıl idaresindeki Nieuport; bir saat on dakika uçarak Çanakkale'de ilk keşfini yapmıştır. Bu keşfe göre, boğazın 10 mil açığında Merkep adası kuzeybatısında Basilic sınıfı iki torpido, bunlardan üç mil ötede İmroz yanında Veymouth Kruvazörü, bu kruvazörün 4 mil açığında Limni istikametinde Defence sınıfı bir kruvazör tespit edilmiştir. Rüzgarın hızını arttırması üzerine uçak geri dönüş yapmıştır. ${ }^{6}$

Eylül ve Ekim 1914'te yapılan ilk keşifler, İngiliz kuvvetlerinin Çanakkale'ye karşı bir harekat hazırlığını göstermesi bakımından önemli olmuştur. Bu keşiflerde İngiliz Deniz Kuvvetleri'nin boğazın ortalama 25 mil açığında dolaştığı, Bozcaada'nın batı ve güneyinde Müttefiklere ait dört muhrip, bir kruvazör, bir muharebe kruvazörü, iki muharebe gemisi, iki denizaltı, iki kömür gemisi ve bir yatın demirlediği; Bozcaada'nın doğusu ve Marmara Burnu dolaylarında da iki İngiliz muhribinin dolaştığ keşfedilmiştir. $^{7}$

19 Ekim 1914'te deniz Yüzbaşısı Savmi, iki kişilik Mahmut Şevket Paşa isimli Nieuport uçağıyla Çanakkale'ye gönderilmiş, ancak uçak yolda arızalandığı için denize inmek zorunda kalmıştır. Bu uçak, deniz üzerinde 24 saat kaldıktan sonra bir motorbotla çekilerek Çanakkale'ye götürülmüştür. ${ }^{8}$

\footnotetext{
5 Mazlum Keyüsk, Türk Havacılık Tarihi: 1912-1918, Uçuş Okulları Basımevi, Eskişehir,1950, s.26.

${ }^{6}$ Yavuz Kansu, Sermet Şensöz ve Yılmaz Öztuna, Havacılık Tarihinde Türkler, Hava Kuvvetleri Basım ve Neşriyat Müdürlüğü, Ankara, 1971, s. 172, Keyüsk, s. 75.

7 Birinci Dünya Harbi Türk Hava Harekat,, IX. Cilt, Genelkurmay Harp Tarihi Başkanlığı Resmi Yayınları, Seri No: 3, Genelkurmay Basımevi, Ankara, 1969, s. 26-27.

${ }^{8}$ Keyüsk, s. 27.
} 
Bunun ardından İstanbul İskenderiye seferi sırasında Çanakkale'ye de ulaşmış olan Ertuğrul isimli Bleriot uçağı Ocak 1915'te Çanakkale'ye sevk edilmiş, böylece bölgeye gelen ilk kara uçağı bu olmuştur. Ertuğrul, Müttefikler Çanakkale'ye karşı bir harekat yapılıp yapılmayacağını tartışırken ve İngiliz deniz uçağı ana gemisi Arc Royal gelmeden, bölgede birçok keşif uçuşu gerçekleştirmiştir.

Son gelen uçaklardan "Ertuğrul" adını taşıyan Bleriot XI-2, Pilotu Teğmen Cemal ile Çanakkale Boğazı'nın ağzına kadar kısa uçuşlar yapabilmişti. Ancak 18 Mart'daki büyük taarruz öncesi Müttefik deniz güçlerinin toplandığı İmroz, Limni ve Bozcaada adalarına uçmak için Bleriot zayıf durumda olduğundan; bu dönemde Müttefik Kuvvetlerin oluşum ve hareketleri hakkında hayati bilgi Çanakkale Komutanlı̆̆ı'na ulaştırılamamıştı. Ertuğrul 22 Mart'ta Çanakkale'den çekilmiş ve İstanbul'a gönderilerek hurdaya ayrılmıştı. ${ }^{9}$

Özellikle bu dönemde ve tüm savaş boyunca hava keşiflerini yakından etkileyen unsurlardan biri iklim koşulları olmuştur. Çanakkale Boğazı bölgesinde Ocak, Şubat, Mart, Nisan, Kasım ve Aralık aylarında her ay 11 gün kapalı ve 6 gün bulutlu geçmektedir. Bu durumda uçuş harekat ve faaliyetleri havanın müsaade ettiği günlerde yapılmış, bu açıdan en yoğun hava hareketi yaz aylarında gerçekleşmiştir. ${ }^{10}$

Genel olarak baktığımızda Çanakkale Cephesi’nin açılması sonrasında tarafların havacılık faaliyetlerinin birinci amacı keşif olmuştur. Çanakkale Boğazı'nın deniz yoluyla geçilmesinin karadan yardım gelmedikçe başarılamayacağının anlaşılması ve çıkarmanın başlamasıyla her iki taraf da havadan bombardıman görevlerini gerçekleştirmişse de, uçak kapasitelerinin sınırlı olması ve ilkel nişan alma metotları nedeniyle çok az görev başarıyla tamamlanabilmiştir. Buna rağmen daha savaş başlamadan bölgede birçok hava faaliyeti gözlenmiştir. ${ }^{11}$

\section{Çanakkale Deniz Savaşı Süresince Havacılık Faaliyetleri}

Çanakkale'de harekatın öncelikli olarak denizden yapılacağı kararı sonrasında, Koramiral Carden'in istediği gemiler Şubat'ın ilk haftasında Limni'de toplanmaya başlamıştı. İngiliz gemilerine destek olarak Fransızların dört zırhlısı ile Rusların Askold adlı hafif bir kruvazörü de bu

\footnotetext{
9 Richard Whistler, "Over the Wine Dark Sea: Aerial Aspects of the Dardanelles, Gallipoli Campaign, Part III, Turco-German Aviation”, Over the Front, Volume: 9, No: 3, 1994, s. 233.

${ }^{10}$ Birinci Dünya Harbi Türk Hava Harekatı, s. 12.

${ }^{11}$ Whistler, s. 230.
} 
kuvvetlere katılmıștı. Böylece 16 zırhlı savaş gemisi, 4 kruvazör, 14 muhrip, 1 uçak ana gemisi, 6 denizaltı, 21 mayın tarama gemisi, 30 dan fazla mayın tarama ve imha botu, 1 muhrip ana gemisi, 1 gambot ve çeşitli yardımc1 gemilerden oluşan toplam 100'den fazla parçadan oluşan bir donanma gücü harekata katılmak üzere hazırlanmıştı. ${ }^{12}$

Çanakkale'de Müttefiklerin büyük harekata hazırlanmaları öncesinde de Türk tarafında keşif çalışmaları devam etmiş̧i. Anılan keşif uçuşlarında temel amaç düşmanın kuvvetlerinin belirlenmesi olmuştur. Bu açidan düşmanın elindeki gemi tipleri, sayıları ve hazırlıklarının takibi için bu uçuşların büyük faydaları olmuştur. Örneğin Mehmet Cemal Bey 1 Şubat'ta Ertuğrul ile keşif uçuşuna çıkmış ve bu uçuşta Boğaz yakınında düşmanın büyük savaş gemilerine rastlamadığını rapor etmişti. Bu süreçte Müttefikler Çanakkale Boğazı çevresine sokulmamakla birlikte keşif uçuşlarına başlamışlardı. Bu amaçla 28 Ocak'ta İngilizler Beşike üzerinde uçmuşlar, 4 Şubat'ta da hem Boğaz civarında hem de Seddülbahir ve Kumkale istihkamları üzerinde uçuş gerçekleştirilmiş, bu uçuşlarda buradaki istihkamlara bomba atılmışsa da bir etkide bulunulamamıştı. ${ }^{13}$

6 Şubat'ta Pilot Cemal bir keşif uçuşu yapmış ve verdiği raporda Merkep Adası ile Bozcaada arasında 2 torpido, 1 denizaltı gördügünü ve uçağının görünmesiyle tam yol ona doğru geldiklerini, Bozcaada civarında da 1 nakliye gemisi, 11 torpido saydığını, uçağına da bir gemiden ateş açıldığını belirtmişstir. ${ }^{14}$

17 Şubat $1915^{\prime}$ te Arc Royal uçak ana gemisi Bozcaada'ya yanaşmıştı. Yedi bin ton hacminde olan bu gemide iki kara Sopwith uçağı ile beş deniz uçağ1 yer almıştır ve bu uçak gemisi Türk topçu mevzilerini keşif etmek ile görevlendirilmiştir. Ancak hava şartlarının kötüleşmesi nedeniyle bu uçaklar etkili olamamıștır. ${ }^{15}$

Arc Royal, ana uçak gemisi olarak inşa edilmiş ilk gemi olması bakımından önemlidir. 1914 yılı Eylül ayında denize indirilen gemi 9 Aralık 1914 'te hizmete girmişti. Arc Royal 17 Şubat'ta Çanakkale'ye gelir gelmez 4 deniz uçağı suya indirilmiş, fakat sadece bir Wight uçağı havalanmayı

\footnotetext{
${ }^{12}$ Erol Mütercimler, Bu Vatan Böyle Kurtuldu, 4. Baskı, Alfa Yayınevi, İstanbul, 2005, s. 104.

13 Ajun Kurter, Türk Hava Kuvvetleri Tarihi, Ankara: 2002, s. 249.

${ }^{14}$ Kansu, Şensöz ve Öztuna, s. 192.

15 İsmail Kayabalı, Cemender Arslanoğlu, Çanakkale Zaferi 1915, Ankara, 1975, s. 84, Keyüsk, s. 63.
} 
başarabilmiş, akşamüstü yaptığı keşifte de tabya ve istihkamları keşfetmiş, bu arada Kumkale ve Seddülbahir'e bomba bırakmıştır. ${ }^{16}$

İtilaf Devletleri uçaklarının Mart başında da uçuşları devam etmiştir. Bu dönemde Arc Royal Seddülbahir civarına gelmiş, bu gemiden kalkan bir uçak Kumkale ve Erenköy Tabyaları'nı gözetlemiş, Dardanos Bataryası üzerine bomba ve çivi atmış, topçumuzun ateşi üzerine geri dönmek zorunda kalmıştır. Bu sırada Ertuğrul adlı Türk uçağı da havalanmış ve Majestic zırhlısını bombalasa da isabet kaydedememiştir. 3 Mart'ta da denizden taarruz olmamasına rağmen Arc Royal'in uçakları Kumkale, Dardanos ve Erenköy tabyaları üzerinde keşif uçuşları yapmışlar ancak yerden açılan şiddetli ateş sonucu geri dönmüşlerdir. Ertesi gün de daha önceki bombardımanların etkisini görmek ve sağlam olan topları tamamen kullanılmaz hale getirmek amacıyla İngiliz gemileri Kumkale civarına bir çıkarma partisi göndermiş, bu harekatta keşif amacıyla İngiliz deniz uçakları da yer almıştır. Uçaklar keşiflerinde tabyalardaki hasarların onarıldığı ve yeni toplar yerleştirildiğini bildirmişlerdir. ${ }^{17}$

13 Mart'tan 18 Mart'a kadar Arc Royal'den kalkan uçaklar yoğun bir hava faaliyetine girişmiş ve bu dönemde birinci amaç mayınların tespiti olmuş, 18 Mart'ta büyük taarruzdan önce de uçaklar alanın mayınlardan temizlendiği konusunda rapor vermişlerdir. 17/18 Mart 1915 gecesi Başkomutanlık karargahı hava müşaviri Yzb. Serno Çanakkale'ye gelmiş ve Rasıtı Kurmay Yzb. Shneider ile Bozcaada yönünde keşif için havalanmış, bu keşifle ada önlerinde harp gemileri, hafif kruvazör, uçak ana gemisi, tamir ve nakliye gemilerinden kurulmuş büyük bir gemi topluluğu görülmüş, böylece düşmanın Çanakkale Boğazı'na saldıracağı kesinleşmiştir. Bu keşifle elde edilen bilgiler derhal boğazın savunulmasından sorumlu Çanakkale Müstahkem Mevki Komutanlığı'na bildirilmiş ve Çanakkale'yi savunan ve böyle bir taarruzu bekleyen bütün birlikler gerekli tertibi almak üzere hazırlanmaya başlamıştır. ${ }^{18}$

Serno anılarında bu keşfi şöyle anlatmaktadır: "1600 metreden uçuyorduk. Bozcaada önünde 40 kadar savaş gemisi saydık. 15'i İngiliz ve 4'ü Fransız olmak üzere 19 ağır zırhlı ve kruvazör, 3 hafif kruvazör, çok sayıda nakliye gemisi, şilep ve uçak ana gemileri gördük; denizaltılar ise ancak seçilebilmekteydi. Savaş düzeninde 6 zırhlı, Boğaz'a doğru yol alıyordu. Amiral forsu Inflexible adlı Ingiliz kruvazörüne toka edilmişti. Arkasinda Queen Elizabeth, Lord Nelson, Agamennon ve Majestic zırhlıları

\footnotetext{
${ }^{16}$ Kurter, s. $249-250$

${ }^{17}$ a.g.e., s. 252.

${ }^{18}$ Birinci Dünya Harbi Türk Hava Harekatı, s. 38.
} 
onu takip ediyordu. Harp flandraları ve işaret flamaları ile süslü Fransız gemileri de yavaş yavaş demir almaktayd. Fransı zırhlisı Bouvet uçağımıza ateş açtı. Zaten kaybedecek zamanımı yoktu, rapor vermek üzere geri döndük.,"19

18 Mart 1915 harekatının birinci amacı Kepez'deki mayın tarlalarını temizlemek için Boğaz'ın savunma tabyalarını susturmak ve bunun ardından Çanakkale Boğazı'nı geçip Marmara'ya ulaşmak olmuştu.

18 Mart'ta Müttefiklerin büyük deniz harekatı öncesinde Nusrat mayın gemisi 7/8 Mart gecesi Erenköy Koyu'na 26 mayın dökmüştü. Deniz yüzbaşısı Hakkı Bey komutasında olan Nusrat mayın gemisi, sabah saat beşte demir alarak yola çıkmış, sisli ve yağmurlu havanın görüş alanını çok daraltmasından faydalanarak, duman çıkarmaması için makinelerinin dakika devrini 140 'da tutmak şartıyla her 15 saniyede bir mayın atarak 26 mayını bölgeye dökmüsstür. ${ }^{20}$ Böylece 18 Mart'ta büyük harekat öncesinde mayınların döşenmesinden habersiz Müttefik Donanması, Müttefik hava keşfinden gelen mayın olmadığ 1 raporu ile beraber harekete geçmiş, ancak büyük bir sürprizle karşılaşarak önemli gemilerini bir gün içerisinde kaybetmiştir. Müttefik uçaklarının bu olayda rasıt görevini tam anlamıyla yerine getirememesi ile de saldırıların seyri bir anda değişmiştir.

18 Mart sabahı Çanakkale deniz savaşı İtilaf Devletleri donanmalarının saldırısı ile başlamış, bu harekat devam ederken Türk uçakları hava keşif görevlerine devam etmiştir. İtilaf kuvvetlerinin savaş gemileri bu taarruz sırasında gerek mayınlar gerekse topçu ateşi nedeniyle birçok gemi kaybederek geri çekilmek durumunda kalmıştır. $\mathrm{O}$ dönemde bin metre yükseklikten sekiz metre derinliğe kadar mayınların görülebileceği kabul edilirken, büyük ihtimalle denizin dalgalı olması mayınların görülmesini engellemiştir. ${ }^{21}$

18 Mart deniz savaşında Türk uçakları erken saatlerde yapılan keşiflerle Çanakkale Müstahkem Mevkii Komutanlığı'na keşfin sonuçlarını zamanında bildirerek Türk birliklerine yardımcı olmuştur. Saat 16.00'da Cemal ve Rasıt Osman Tayyar, Bleriot ile Boğaz dışına bir keşif yapmış, Seidler ve Deniz Yüzbaşı Hüseyin Sedat ise Rumpler ile ikinci keşfi gerçekleştirmiştir. Burada $80 \mathrm{~km}$. kadar batı yönünde uçarak Limni'yi keşfetmişler, bu keşifler sırasında düşmanın kesin olarak çekildiği anlaşılmıştır. İlerleyen günlerde yağmur ve firtına hava keşiflerine engel olmuş, 22 Mart'ta Türk topçuları bir İngiliz deniz uçağını Saroz Körfezi'ne düşürmüştür. 26 Mart'ta Serno ve

\footnotetext{
${ }^{19}$ Artuç, s. 68.

${ }^{20}$ Kayabalı ve Arslanoğlu, s. 71.

${ }^{21}$ Keyüsk, s. 64, Kansu, Şenöz ve Öztuna, s. 196.
} 
Scheider yeni bir keşif uçuşu yapmış ve verdikleri rapordan yeni bir donanma taarruzunun söz konusu olmayacağı anlaşılmıştır. İki Albatros B I, bu sırada Çanakkale'ye gelmiştir. ${ }^{22}$

Bahriye Harekat1 isimli İngiliz resmi savaş tarihinin II. Cildinde 18 Mart 1915 Çanakkale harekatı şu şekilde analiz edilmişti: ${ }^{23}$

"Felaketin gerçek sebebi bulunup saptanıncaya kadar çok vakit geçmemiştir. Gerçek sebep şudur: Türkler 8 Mart gecesinde bizim haberimiz olmadan Erenköy Koyu'nun içinde ve sahile paralel 26 mayın dökmüşler, balıkçı gemilerimiz yaptıkları aramalarda bunlara rastlayamamıştır. Türkler bu mayınları özel amaçlarla bizim daimi manevra alanımıza yerleştirmişler, gösterdiğimiz tüm ihtiyat ve ön görülülüğe rağmen baş döndürücü bir zafer kazanmışlardır."

Çanakkale Boğazına Müttefik Donanması'nın saldırısından sonra İngiliz Krallık Donanma Hava Servisi Çanakkale'de yapılan harekatın bu ilk aşamasında deniz uçaklarının yetersiz kalması nedeniyle bölgeye bir kara uçak birliği gönderilmesini kabul etmişti. 24 Mart 1915'te Binbaş1 Samson'un emrinde bir uçak birliği Bozcaada'ya ulaşmıştı. 8 Hanri Farman, 3 Moris Farman, 1 Brege, 2 Sopwhit, 2 BE 2e ve 2 BE tipi 18 uçak bu birlikte yer almıştır. Hava Komodoru Samson Bozcaada'da Rum kadınların yardımıyla bağlık bir alanı söktürerek, bu bölgeyi içleri çimento dolu bidonlarla düzleştirip 700-800 metre boyunda bir pist inşa edilmesini sağlamıştı. Buradan Seddülbahir'e 40, Anzak Kolordusu'nun çıkacağ Kabatepe'ye ise 60-70 km uzaklık vardı ve bu mesafeler o zamanki uçakların şartlarına göre çok fazla olmasına rağmen, Samson yanına kiloca zayıf subaylardan gönüllüleri de alıp keşif uçuşlarına devam etmiştir. ${ }^{24} \mathrm{Bu}$ 16 uçaklık havaalanı dışında Seddülbahir'de de 4 uçaklı bir havaalanı kurulmuştur. Seddülbahir'deki İngiliz havaalanı Türk topçuları tarafından ateş altına alınmış ve yerde yakalanan bir İngiliz uçağı tahrip edildiğinden, daha çok Bozcaada'daki havaalanından faydalanılmıştır. ${ }^{25}$ Binbaşı Samson

22 Rezzan Ünalp, "Turkish Air Operations During the Dardanelles Campaign", Communiqués the Joint Turkish - Israeli Military Conference I (9-12 April 2000 İstanbul), Genelkurmay Askeri Tarih ve Stratejik Etüt Başkanlığı Yayınları, Genelkurmay Basımevi, Ankara, 2000, s. 128-129.

${ }^{23}$ Kayabalı ve Arslanoğlu, s. 60.

24 Alan Moorehead, Çanakkale Geçilmez: Gallipoli, (çev: Günay Salman), Milliyet Yayınevi, İstanbul, 1972, s. 157-158.

${ }_{25}$ Türk Silahlı Kuvvetleri Tarihi Osmanlı Devri Birinci Dünya Savaşında Türk Harbi, Çanakkale Cephesi Harekatı (Haziran 1915 - Ocak 1916), V. Cilt, 3'ncü Kitap, Genelkurmay Askeri Tarih ve Stratejik Etüt Başkanlığı Tarih Yayınları, Seri No:3, Genelkurmay Basımevi, Ankara, 1980, s. 514. 
komutasındaki birlik Bozcaada'nın kuzeyinde havaalanına yerleşmiş ve kara uçaklarının gelmesi ile Arc Royal uçak gemisi hareket serbestîsi kazanarak Türk sahillerinde keşif yapmaya başlamıştı. Çanakkale'de uçaklarla yapılan keșiflerin verimli olmaması üzerine Manica gemisinin içindeki sabit balon İngiltere'den yola çıkarak bölgeye gönderilmiştir. ${ }^{26}$

18 Mart'tan Çanakkale'de kara savaşlarının başladığı 25 Nisan'a kadar geçen sürede Müttefikler genel olarak keşif çalışmalarını yürütmüş, bu arada boğazın sadece denizden geçilemeyeceği anlaşıldığından yarımadanın Avrupa kıyılarına asker çıkarma planları yapılmaya başlanmıştı.

Çanakkale'nin denizden zorlanması sonrasında düşmanın yeniden taarruza mı geçeceği yoksa karaya asker mi çıkaracağının anlaşılması için hava muhalefeti nedeniyle aksayan hava keşifleri 26 Mart'ta yeniden başlamış, ilk olarak Bozcaada istikametinde birkaç İngiliz gemisi tespit edilmişti. Aynı günün öğleninde Pilot Seydler ve Rasıt Deniz Yüzbaşısı Hüseyin'in yönetimindeki uçak, Limni' de İngiliz gemilerini tespit etmesine rağmen düşmanın donanma ile yeniden taarruza geçeceğine ve asker çıkaracağına dair bir işaret görülmemişti. ${ }^{27}$

$\mathrm{Bu}$ dönemde tarafların hava birliklerinde idari anlamda değişikliğe gidilmişti. Buna göre, Çanakkale'de bulunan üç uçak, Alman pilotları Yeşilköy'de eğitilmiş üç Türk subayı ve Alman bakım personeli ile 1 nci Türk Tayyare Bölüğü oluşturulmuş, bu bölükteki Alman sivil pilotlarına teğmen, makinistlerine astsubay rütbesi verilmişti. Tayyare Bölük Komutanlığı'na Alman Pilot Teğmen Christoph Preussner getirilmiş ve bölük Müstahkem Mevki Komutanlığı emrine girmiştir. Üç uçaktan oluşan 1 nci Türk Tayyare Bölüğü 27 Mart 17 Nisan 1915 arasında Çanakkale Boğazı üzerinde birçok keşif yapmış, bu aşamada Müttefik gemilerinin çoğunun Mondros Koyu'nda demirli olduğu tespit edilmiş, bir çıkarma için hazırlık yapıldığı görülmemiştir. ${ }^{28}$

1nci Tayyare Bölügü harekat uçakları dışında eğitim çalışmalarında da bulunuyordu. Bunun yanı sıra devamlı uçan uçaklarda arızalar da görülüyordu. Büyük arızaları bölük meydanında gidermek mümkün olmadığ için, uçaklar gemi ile İstanbul'a gönderiliyor, bu nedenle de bu uçaklardan yaklaşık 10 gün yararlanılamıyordu. Ayrıca Çanakkale Meydanı'nın çok taşlı olması ve taşların dönen pervanelere çarpması hasar

\footnotetext{
${ }^{26}$ Keyüsk, s. 64-65.

${ }^{27}$ Birinci Dünya Harbi Türk Hava Harekatı, s. 39.

${ }^{28}$ a.g.e., s. $39-40$.
} 
ve kırıma yol açıyordu. Tüm bu nedenlerden dolayı zaten sadece üç uçaktan oluşan bölük, bazen uçuşa tek uçak bile çıkartamıyordu. ${ }^{29}$

Müttefiklerin hava üstünlüğünü elinde bulundurduğu bu süreçte Çanakkale Deniz Savaşları kesin olarak Türk zaferiyle sonuçlandırılmıştı. $\mathrm{Bu}$ aşamada uçaklardan taarruz amaçlı olarak çok faydalanılmamış, keşif amaçlı uçuşlar dışında havada Müttefiklerle karşı karşıya kalınmamıştır. Bu nedenle deniz savaşları süresince Türk uçakları daha çok savunmada kalmayı tercih etmiştir.

\section{Gelibolu Çıkarması Süresince Havacılık Faaliyetleri}

Çanakkale Deniz Savaşları'nda başarılı olamayan İtilaf devletleri bu aşamada bekleme durumuna geçmiş, bu süreçte de tarafların uçakları keşiflerini aralıksız sürdürmeye devam etmiştir.

18 Nisan'da Çanakkale'de yoğun bir hava faaliyeti olmuş, 1nci Bölük uçakları Bozcaada'ya uçuş yaparak 3 ncü Filo'nun meydanına 2 bomba atmış, buna cevap vermek isteyen 3 deniz uçağı Çanakkale meydanına gelerek 3 bomba bırakmıştır. Öğleden sonra da Müttefik bombardımanı tekrarlandığı için 1nci Bölük uçakları meydandan çekilerek gizlenmiştir. ${ }^{30}$ $\mathrm{Bu}$ süreçte keşifler devam etmiş ve bunların en önemlisi Yüzbaşı Hüseyin Sedat'ın raporunda görülmüştü. Bozcaada'nın batısındaki çok yüklü bir düşman nakliyesinin içerisinde askerlerle beraber Limni'ye doğru seyrettiği görülmüş, 23 Nisan'da Mondros Koyu keşfedilmiş, yine Yüzbaşı Hüseyin'e göre adadaki kıtalar silahlanmış ve 26 nakliye gemisinin beklediği görülmüştür. Böylece Çanakkale'nin karadan zorlanacağı kesin olarak anlaşılmıştır. ${ }^{31}$

Müttefik kuvvetlerinin Çanakkale'ye yakın adalarda bulunmaya devam etmesi ve Mondros Koyu'ndaki donanma kuvvetlerinin artan şekilde gelmesi üzerine boğaza bir taarruz yapılacağı kesinleşmiş, 25 Nisan sabahı da Seddülbahir, Arıburnu ve Kumkale'ye çıkarma başlamıştır.

Gelibolu'ya asker çıkarılması kararıyla beraber 25 Nisan'da önce yarımada ve Trakya arasında Saroz Körfezi'ne ve boğazın ağzında Anadolu köşesine gösteriş çıkarmaları yapılmaya başlanmış, ertesi gün de Seddülbahir çıkarması kesin olarak başlamıştı. Bu süreçte Müttefik Kuvvetlerin karaya çıkışından sonra 1nci Tayyare Bölüğü, çıkarma bölgelerine uçuşlarını yoğunlaştırmaya başlamıştır.

\footnotetext{
${ }^{29}$ Kurter, s. 279-280.

${ }^{30}$ a.g.e, s. 281

${ }^{31}$ Kansu, Şensöz ve Öztuna, s. 198.
} 
25 Nisan'da İtilaf kuvvetleri Seddülbahir, Arıburnu ve Kumkale'ye çıkarma yapmaya başlamış, ancak Türk direnişi karşısında Seddülbahir ve Arıburnu'nda bir varlık gösterememiş, sadece küçük bir alanda köprübaş1 elde edebilmişti. İtilaf kuvvetlerinin şiddetli bombardımanı ile başlayan çıkarma harekatı sırasında Pilot Garber ve Yüzbaşı Hüseyin Sedat keşif uçuşlarına devam etmişti. Saroz Körfezi'nden Anadolu sahiline kadar yapılan üç saatlik keşifte 45 nakliye gemisi tespit edilmiş, savaş gemilerinin Saroz'a karşı bir çıkarma yapmakta olduğu tespit edilmiştir. Ancak keşfin bu çok önemli sonuçları, uçak bölüğü Mevkii Müstahkeme bağlı olduğundan 5 nci Ordu'ya ulaştırılamamış daha sonrada uçakların arızalanması nedeniyle başka uçuş yapılamamıştır. ${ }^{32}$

3 ncü Filo, 25 Nisan tarihinde Müttefik çıkarma harekatında Seddülbahir Mevkiindeki Ertuğrul Koyu ve Teke Koyu'na yapılan çıkarmaları desteklemekle görevlendirilmişti. İngiliz uçakları temel olarak kıyıdaki Osmanlı savunma mevzilerini bastırmakla görevli olan gemilerin top atışlarını tanzim etmek üzere sabah erkenden uçmaya başlamıştı. Görev yapmaya müsait durumdaki altı uçak da, en az iki sorti ve bazıları üç sorti uçarak tüm gün boyunca kullanılmıştır. Ancak bu faaliyetler hem top atışlarının tanzimindeki tecrübesizlikten, hem de gemilerin uçaklardan gelen mesajlara aldırmamasından dolayı boşa harcanan bir çaba olmuştur. ${ }^{33}$

Bir görüşe göre harekatta kıyı savunmasını top atışlarıyla bastırmakla görevli gemilerin uçakların mesajlarına aldırmamasının temel nedeni, gemilerin kıyılarda bulunan birçok hedefle meşgul olduklarından hava gözetleme mesajlarını çok dikkate alamadıkları şeklindendir. Ancak gemilerin denizdeki alçak konumlarından yarımadanın coğrafi yapısı nedeniyle iyi gizlenebilen Osmanlı savunma birliklerinin yerlerini görerek atış yapması mümkün değildi. Eğer kıyıdaki görüş alanı içerisindeki hedeflere değil, hava keşfi ile tespit edilen savunma mevzilerine derinlemesine karşı bombardımanda bulunulsaydı, çıkarma başarılı olabilirdi. ${ }^{34}$

$\mathrm{Bu}$ tarihlerde, İtilaf Kuvvetleri Çanakkale çıkarmasına 20 İngiliz kara uçağı, 8 Fransız kara uçağı, 2 İngiliz deniz uçağı ve 12 Fransız deniz uçağı olmak üzere, toplamda 42 uçaktan oluşan bir hava kuvveti tahsis etmişti. ${ }^{35}$

\footnotetext{
${ }^{32}$ Kansu, Şensöz ve Öztuna, s. 198, Birinci Dünya Harbi Türk Hava Harekatı, s.43.

${ }^{33}$ Bülent Yılmazer, Çanakkale Hava Savaşları, Mönch Türkiye Yayıncılık, Ankara, 2005, s. 79.

${ }^{34}$ a.g.e., s. 69.

${ }^{35}$ Keyüsk, s. 65-66.
} 
Nisan sonundan itibaren Çanakkale'de Müttefikler, Alman denizaltılarının gelmesiyle, Boğaz bölgesinde hareket serbestisini de yitirmişlerdi. Mayıs ayında iki zırhlının torpillenmesiyle Arc Royal gemisinden kalkan uçakların keşif çalışmaları aksamıştı. Bu nedenle anılan uçaklar denizaltılara karşı da keşif çalışmalarıyla görevlendirilmişti. İtilaf Devletleri'nin Seddülbahir'e top ateşiyle büyük bir taarruza girişmesine rağmen başarılı olamaması ardından, Mayıs başında Türk Ordusu da karşı saldırıya geçmiştir. Ancak bu kara savaşları her iki tarafın da büyük kayıplar vermesine neden olmuştur. Bunun ardından İngiliz Başkomutanlığı'nın yeni hedefi Alçıtepe'yi ele geçirmek olmuştur.

Alçıtepe'nin ele geçirilmesi halinde, Alçıtepe kuzey yamaçlarında mevzilenen Türk topçularının Alçıtepe Bölgesi'ndeki gözetleme yerlerinden faydalanarak Seddülbahir mevziindeki İngiliz ve Fransız birliklerine yapmakta olduğu ateşten kurtulunması sağlanacak, gerek Seddülbahir kesimindeki birliklerin muharebe gemileriyle desteklenmesi ve gerekse Morto Limanı veya Teke Koyu'na dayanan lojistik desteğin daha kolay ve güvenli yapılması mümkün olacaktı. ${ }^{36}$

Kumkale'ye yapılan çıkarma sırasında İngiliz uçakları kendi birliklerinin taarruzunu desteklemiş, Arıburnu Bölgesi'ne yapılan çıkarma sırasında Arc Royal uçak ana gemisinden kalkan 6 uçak da görev almıştır. ${ }^{37}$ Buna karşılık Gelibolu Yarımadası ve Kumkale'ye çıkarma yapıldı̆̆ı sırada, Türk Ordusunda üç kara, bir deniz uçağından oluşan tayyare bölüğü, Müstahkem Mevki Komutanlığı emrinde bu komutanlığın verdiği görevleri üstlenmiş, ancak 5 nci Ordu emrinde uçak olmadığı ve iki komutanlık arasında uçakların kullanılması konusunda bir anlaşma sağlanamadığı için, çıkarmada Türk uçaklarından yeterince yararlanılamamıştır. ${ }^{38}$

Bunun yanı sıra Türk tarafinın Seddülbahir ve Arıburnu çatışmalarında uçaklardan bombardıman amaçlı verim alamamasının bir nedeni de ateş hattında uzaktan elle atılan bombaların çok etkili olmamasıdır. Örneğin Helles (İlyas) Burnu Plajı açıklarında ateş destek ve keşif görevini yerine getiren İngiliz zırhlısı Euryalus'ta bulunan bir gözetleyici, 30 Nisan'da bir uçağın savaş gemisinin üstünden uçtuğunu ve denize düşüp patlayan bombalar attığını belirtmiştir. Ancak genel olarak hava bombardımanıyla hiçbir müttefik savaş gemisine zarar verilememiştir. ${ }^{39}$

\footnotetext{
${ }^{36}$ Türk Silahlı Kuvvetleri Tarihi, s. 28.

${ }^{37}$ a.g.e, s. 517.

${ }^{38}$ Birinci Dünya Harbi Türk Hava Harekatı, s. 43.

${ }^{39}$ Ünalp, s. 130.
} 
İtilaf devletlerinin çıkarması sırasında İngiliz Manica gemisinin üstünde yükselen sabit balonun savaş sırasında gemi ve kara topçularının idaresini başarıyla yerine getirmesi sonucu, birliklerimiz ağır kayıplar vermiştir. Manica'ya bağlı olan balon 25 Nisan sabahı göreve başlamış ve Anzak çıkarmasına destek amaçlı olarak aralıksız sekiz saat havada kalarak, Triumph savaş gemisiyle yakın işbirliği içerisinde çalışmıştır. Bu balon sayesinde Triumph savaş gemisi Osmanlı savaş gemisi Turgut Reis'in üç kere yerini değiştirmesine neden olmuş, çıkarma sırasında Anzak kayıplarının artmasını önlemiştir. Çıkarma harekatını takip eden günlerde de Manica birçok kez balon uçurarak Queen Elizabeth ve Triumph'un kıyıdaki hedeflere atışını düzenlemiştir. ${ }^{40} \mathrm{Bu}$ konuda 5 nci Ordu Komutanlığı'ndan Karargah-1 Umumiye'ye acil kaydıyla yazılan şifrede bu konu şu şekilde dile getirilmiştir: ${ }^{41}$

"En çok zayiatımıza sebep olan düşmanın sabit balonunun tarassudatıdır. Yüzbașl Serno'nun bu balona taarruz etmesi lazımdır. Mumaileyhin Uzerdum Paşa'nın emrinde mi yoksa benim mi emrimde olduğunu bilmiyorum. Balon yalnız kitaatımızı tarassut ediyor. Tarassut halatı iki bin metre uzundur. Tekmil düşman sefain ateşini mezkûr balon idare ediyor. Dün Kirte'nin garbında sahilden nısfi sefinei harbiye olmak üzere 45 düşman sefinesi saydım. Hastaneyle beraber Maydos'un dünkü bombardımanı pek adi bir hareketti. Bugün Gelibolu'ya tayyareden bomba atılmış, bir nefer şehit, bir kadın maktul, bir çocuk ağır mecruhtur. 30 Nisan 1915."

Canakkale Cephesi'nde ilk hava savaşı 2 Mayıs 1915'te gerçekleşmiştir. Albay Serno komutasında ve Yüzbaşı Hüseyin Sedat rasıdında keşif için havalanan Türk uçağ 1 , düşman uçağıyla karşılaşınca havacılarımız Parabellum tabancalarıyla karşı uçağa ateş açmış ve bu uçağı püskürtmeyi başarmışlardır. ${ }^{42} \mathrm{Bu}$ dönemde Çanakkale'de mevcut kara uçaklarına takviye olarak Almanya'dan deniz uçakları istenmiş, Alman İmparatorluk Donanma Dairesi de bir miktar Gotha WD 1 deniz uçağını, sivil havacı ve makinistlerinin yanı sıra, rasıt olarak görev yapmak üzere ticari gemi subaylarıyla göndermiştir. ${ }^{43}$ Keşif uçuşları 3 ve 4 Mayıs tarihlerinde sürmüş, 4 Mayıs'ta 1 nci Tayyare Bölüğü'ne ait 2 uçak

\footnotetext{
${ }^{40}$ Y1lmazer, s. 65.

${ }^{41}$ Keyüsk, s. 68, Birinci Dünya Harbi Türk Hava Harekatı, s. 42-43.

${ }^{42}$ Cemal Anadol, Türk Havacılık Tarihi, İstanbul, 1990, s. 97, Fikret Alasya, "Türklerde Havacılık”, Türk Kültürü, Sayı: 34, Ağustos 1965, s. 101-102.

${ }^{43}$ Yilmazer, s. 89.
} 
Seddülbahir önlerindeki düşman nakliye gemileri ve karaya çıkarılmakta olan askerlere bomba hücumu yaptıysa da bir sonuç elde edilememiştir. ${ }^{44}$

Mayıs 1915'te Türk uçakları keşiflerine devam etmiş, bu dönemde Arıburnu önünde yer alan İngiliz balon gemisi Manica ciddi tehdit olmaya başlamış, yapılan uçuşlarda bu balona saldırıldıysa da atılan bombaların küçük çapta olması dolayısıyla etkili olunamamıştır. 14 Mayıs'ta Seddülbahir'deki düşman ordugahı uçaklarımız tarafindan bombalanmış, 19 Mayıs'ta ise iki uçağımız güney cephesindeki bir taarruza destek olarak düşman çıkarma gemilerini ve ordugahını bombalamıştır. ${ }^{45}$

Çanakkale Cephesi'nde Mayıs'ın ortasına kadar önemli çatışmalar olmamış, ancak Haziran başında İtilaf kuvvetleri taarruza geçmiş ve savaşın başından beri en kanlı çatışmalar bu dönemde gerçekleşmiştir.

23 ve 27 Mayıs hava keşifleri düşman taşıt ve savaş gemilerinin durumunu öğrenmek açısından faydalı olmuştur. 28 Mayıs'ta yapılan keşif uçuşlarında bir gün önce Alman U-2 denizaltısı tarafından batırılan Majestic zırhlısının Seddülbahir feneri dolaylarında ters dönmüş olarak su altında yatmakta olduğu anlaşılmıştır. ${ }^{46}$

31 Mayıs 1915 'te yapılan dört saatlik keşifte İmroz, Limni, Seddülbahir ve Anafartalar çevresinde birçok gemi tespit edilmiş, Kefalo Limanı'nda King Edward sınıfı bir muharebe gemisi, Juno tipinde ufak bir kruvazör, iki torpido, dokuz nakliye, bir kurtarma ve bir balon gemisi; İmroz adas1 ağzında iki taburluk ordugah, Mondros Limanı'nda Agamemnun tipinde bir gemi, Majestik, Triumpth, Prince of Wales, Russel, Ocean sinıfindan Hanri IV Fransız muharebe gemisi ile İngiliz Kress, Juno, Hingflier kruvazörleri, Fransız Julferry, üç gambot, dört hastane gemisi, altmış nakliye gemisi, dört Fransız torpido muhribi, Mondros Limanı önünde orta gemiler için bir mayın hattı geçidi, Limni Adası doğusunda bir tümeni barındıracak 15 bin kişilik ordugah ve birçok hayvan ve malzeme görülmüş, limana iki bomba atıldığı bildirilmiştir. ${ }^{47}$

4-5 Haziran'da başlayan Üçüncü Kirte Savaşının ardından da 12 Haziran'da Kerevizdere'de yoğun çatışmalar başlamıştı. Ağustos ayında Anafartalar'a yapacağı çıkartmanın başarısını garantilemek isteyen düşman, Türk Komutanlığı'nın dikkatini güney bölgesine çekmek amacıyla 12 Temmuz'da çok şiddetli bir topçu hazırlığından sonra Kerevizdere'ye

\footnotetext{
${ }^{44}$ Kurter, s. 284.

${ }^{45}$ Kansu, Şensöz, Öztuna, s. 200.

${ }^{46}$ Kayabalı ve Arslanoğlu, s. 92.

47 Birinci Dünya Harbi Türk Hava Harekatı, s. 45.
} 
dalgalar halinde taarruza geçmiştir. Savaşın başından beri taraflar en fazla zayiatı bu bölgelerde vermiştir. Haziran başında gerçekleşen muharebeler sırasında İngiliz, Fransız Kara ve Hava Kuvvetleri, tüm olanaklarını kullanarak yaptıkları keşiflerle, Türk savunma düzenlerini büyük ölçüde doğru olarak saptamıştı. Özellikle deniz hava kuvvetlerinin çektiği fotoğraflara göre hazırlanan krokiler Türk savunma mevzilerini tüm ayrıntılarıyla kapsamıştı. ${ }^{48}$

Bu süreçte Türk uçaklarının yaptığı keşiflerde, İngilizlerin 2 yeni tümen sevki ile takviye edildikleri görülüyordu. Müttefikler Haziran başında 3 ncü Kirte Savaşı olarak bilinen taarruzu başlatmış, donanma gemileri bu taarruzda yoğun bir ateş desteği sağlamıştı. Bu çarpışmalarda her iki taraf da uçaklardan faydalanmıştır. Güney grubu komutanı Vehip Paşa Türk birliklerine çok kayıp verdiren Kanlıdere ve Seddülbahir'deki top bataryalarının yerlerinin mutlaka saptanmasını istemiş, 1nci Tayyare Bölüğü'ne ait bir uçak bu görev için 4 Haziran'da havalanmış ve görülebilen bataryaların yerlerini haritaya işaretlemişti. ${ }^{49}$

6 Haziran'da Türk uçakları düşman mevzilerini bombalamış, bu bombardımanın sonrasında uçaklar bakıma alındığı için, 13 Haziran'a kadar herhangi bir hava harekatı planlanıp gerçekleştirilememişti. $\mathrm{Bu}$ tarihten sonra yapılan keşif uçuşlarında Limni Adası'nın Mondros koyunda o zamana kadar keşfedilenlerden daha büyük bir çadır ve barakalar topluluğu ile 18 düşman gemisinin bulunduğu; koyun doğusunda ordugah kurulduğu, Bozcaada'nın kuzeyinde bir muharebe gemisi ile beş muhribin, İmroz Kefalo Limanında iki muhrip ile iki muharebe gemisinin, ada güneyinde üç mayın tarama gemisinin, Suvla, Arıburnu ve Seddülbahir'de ise muhtelif muhrip ve arama tarama gemilerinin bulunduğu tespit edilmiştir. ${ }^{50}$

9 Haziran'da 4660 tonluk bir başka balon gemisi olan Hector da Çanakkale'ye gelmişti. Manica Eylül sonuna doğru onarım amaciyla İngiltere'ye dönmüş, Hector da 1916 yılının ilk aylarına kadar cephede görev almıştı. Osmanlı topçusunun balonu düşürme girişimleri nedeniyle, bu balon kıyıdan uzakta uçurulmuş ve rasıdın görüş alanı azaldığı için çok etkili olamamıştı. ${ }^{51}$

Haziran boyunca Türk uçaklarının yaptığı hava keşifleri aralıksız sürmüş, 15 Haziran'da düşmanın Seddülbahir'de kurduğu dört uçaklı havaalanı, Türk topçusu tarafindan bombalanmış, üç düşman uçağı

\footnotetext{
${ }^{48}$ Türk Silahlı Kuvvetleri Tarihi s. 35.

${ }^{49}$ Kurter, s. 287.

${ }^{50}$ Birinci Dünya Harbi Türk Hava Harekatı, s. 46.

${ }^{51}$ Yilmazer, s. 65.
} 
havalanarak alanı terk etmek zorunda kalmıştı. 18-19 Haziran keşiflerinde yeni bir faaliyet görülmemiş, 20 Haziran'da Midilli, Bozcaada, İmroz, Limni üzerinde uçuşlar yapılmış, 21 Haziran'da yapılan büyük çıkarma sonrasında ise, topçumuz denize iki uçak düşürmeyi başarmıştı. 22 Haziran'da güney cephesi bombalanırken hava muharebesi gerçekleşmiş, bir İngiliz rasıdı vurulmuş, bir uçağımız da motoruna ateş isabet ettiği için Alibey Çiftliği yanına iniş yapmak zorunda kalmıştır. 25 Haziran'da yine bir ilk olarak düşman karargahları üzerine havadan bildiriler atılmış, böylece uçaklardan propaganda amaçlı yararlanılmasının bir örneği de yaşanmıştır. 23-25 Haziran arasında uzun mesafe keşifleri devam etmiş ve bölgede 100 gemi tespit edilmiştir. ${ }^{52}$

20 Haziran'da 1nci Bölük uzak keşif için görevlendirilmiş ve ilk kez Midilli adasına bir keşif yapılmış, burada denizaltı devriye ve karakol uçuşları için kullanıldıkları sanılan birkaç deniz uçağı görülmüş ve aynı gün Bozcaada, İmroz, Limni Adalarına da uçuş yapılarak Limni Adası'nın Mondros körfezinde demirli bulunan nakliye gemilerinin güvertelerine nakliye botları yerleştirildiği belirlenmiştir. Böylece yakında Gelibolu Yarımadası'na yeni birliklerin çıkarılacağı ve taarruz yapılacağı sonucuna varılmıştı. ${ }^{53}$

Limni ve Bozcaada dolaylarında karargah ve gemilerin artmas1 hakkında hava keşifleriyle elde edilen bilgiler, düşmanın Seddülbahir veya Arıburnu'na yeniden taarruza geçeceğine dair hazırlık yapmakta olduğunu göstermişti. 28 Haziran 1915 'te kuvvetli topçu desteği ile Zığındere'de taarruza geçen düşman, Türk Cephesi'nin sağ kanadını çökertmiş, Çanakkale'nin iç tabiyelerinin düşürülmesini hedef tutarak Alçıtepe'yi ele geçirmek istemişti. Muharebelerin sonrasında vaktinde yetişen takviye kuvvetlerinin cepheye sokulmasıyla düşman taarruzu durdurulmuştu.

$\mathrm{Bu}$ muharebeler sırasında, düşman takviye kuvvetlerinin ve ikmal nakliyatının hava keşfi ile meydana çıkarılmasına önem verilmiştir. 29 Haziran 1915 'te Seddülbahir'deki düşman birliklerini bombalamak üzere görevlendirilen iki uçaktan birisi kalkış sırasında hasar görmüş, diğeri ise görevini tamamlayarak üsse dönmüştür. ${ }^{54}$

Haziran 1915'te Kraliyet Hava Birlikleri'nin isimlerinde meydana gelen değişikliğe paralel olarak 3 ncü Filo, 3 ncü Hava Alayı olarak anılmaya başlanmıştır. Alayın kara uçakları Arc Royal'in deniz uçaklarının görevlerini devralmış, Arc Royal Ege Denizi ve Doğu Akdeniz'de görev yapmak için

\footnotetext{
${ }^{52}$ Kansu, Şensöz ve Öztuna, s. 201, Birinci Dünya Harbi Türk Hava Harekatı, s.46-47.

${ }^{53}$ Kurter, s. 288.

${ }^{54}$ Birinci Dünya Harbi Türk Hava Harekatı, s. 47.
} 
ayrılmış, Alman denizaltısı U21'in bölgedeki operasyonları sonucu kesin olarak çekilmiştir. ${ }^{55}$

29 Haziran'da 1nci Bölük, 2 uçakla Seddülbahir'i keşif için görevlendirilmiş, bu iki uçaktan biri kalkış sırasında kazaya uğrayarak kırım yapmış, diğer uçak görevini tamamlayarak geri dönmüştü. Bu dönemde bölük uçakları bombardıman ve yakın keşif uçuşunu en fazla 600-800 metreden yaptığı için yerden açılan piyade ateşinden etkileniyor, hatta kendi birliklerimizin ateşine de maruz kalıyordu. Alman kaynakları bunun nedenini; Türk uçaklarının Alman demir haç işareti ile uçmalarına ve Türk birliklerinin bu işareti bilmediklerine bağlamakla beraber gerçekçi görülmemektedir. Türk askeri uçaklarında savaşın başından beri dikey stabilize ve dümende kırmızı zemin üzerinde beyaz ay yıldızın olduğu ve kanat altlarında da dıştan içe kırmızı beyaz kırmızı renkli üç daireden oluşan bir tanıtma işaretinin kullanıldığı bilinmektedir. İngiliz ve Fransız uçaklarının da kanat altlarında 3 renkte olmak üzere iç içe 3 daireden oluşan bir tanıtma işareti kullanılmaktaydı. Özellikle Fransız uçaklarında bu daireler dıştan içe doğru kırmızı, mavi, kırmızı şeklindeydi. Dolayısıyla ortadaki en küçük daire dışında, Türk askeri işaretine çok benzediğinden, Fransız ve Türk uçakları karıştırılabiliyordu. ${ }^{56}$

Temmuz ayında İngiliz ve Fransızların toplam uçak sayısı 55'e yükselmişti. Bu yüzden düşmanın hava harekat imkanı da artmıştı. Müttefik hava gücü sayı ve nitelik bakımından üstün olmasına rağmen Türk tarafı düşmanla direkt temastan kaçınarak ve firsatlardan yararlanarak keşif ve bombalama faaliyetlerine devam etmiştir.

Çıkarma harekatı boyunca Kraliyet Donanması, Türk mevzilerini bombalamayı sürdürmüş ve o dönem deneme aşamasında olan havadan topçu mevzilerini tespit etme tekniği de kullanılmaya başlanmıştır. ${ }^{57} \mathrm{Bu}$ dönemde bölgedeki Türk uçak birliği de takviye sağlamış olup Almanya'dan gelen 2 Gotha deniz uçağı ve Alman deniz havacılarından kurulu küçük bir deniz birliği, Mevkii Müstahkem emrine verilmiştir. Alman Donanması özel müfrezesi de "Deniz Uçak Birliği” adı altında 5-6 Temmuz'da keşiflere başlamışıtır. ${ }^{58}$

5 Temmuz 1915'te de İngiliz ve Fransız uçaklarının müdahalesi ile iki Türk uçağı yerde tahrip edilmiştir. Bunun yanı sıra Marmara Denizi’nde dolaşan İtilaf kuvvetleri denizaltı gemilerine hedef bulmak suretiyle yardım

\footnotetext{
${ }^{55}$ Yilmazer, s. 69.

${ }^{56}$ Kurter, s. 289-290.

${ }^{57}$ Ünalp, s. 129.

${ }^{58}$ Kansu, Şensöz, Öztuna, s. 201.
} 
eden İngiliz uçakları, Saroz Körfezi'ne giren gemilerden kalkarak kendilerine verilen keşif görevlerini sürdürmüş, ayrıca E 14 Denizaltı gemisi tarafindan yara alan Mahmut Şevket Paşa vapuruna torpido atarak tahrip olmasına neden olmuştur. Deniz savaşları tarihinde ilk kez görülen bu olay torpido uçakları fikrinin doğmasına neden olmuştur. ${ }^{59}$

5 Temmuz keşfinde zarar gören iki Türk uçağının kullanılamaz hale gelmesi ile beraber, Türk Tayyare Bölügü 5 nci Ordu emrine girdikten sonra mevcut uçaklardan üçü kullanılamaz duruma gelmiş, bölük bir süre uçuşa ara vermek zorunda kalmıştır. Bu nedenle yeni uçak temini için Yüzbaşı Serno Almanya'ya gönderilmişti. ${ }^{60}$ Aynı gün 2 Gotha WD I tipi deniz uçakları ve Alman uçucular Çanakkale'ye gelmiş, bunlar Çanakkale'nin kuzeyinde Köse ve Nara burunları arasındaki istasyonda konuşlandırılmıştı. $\mathrm{Bu}$ uçaklar ve İstanbul'da görevli bir diğer uçak Alman İmparatorluk Donanması Türkiye Özel Komutanlığı'nın Deniz Uçak Birliği'ni oluşturmuştu. Birliğin taktik olarak Boğazlar Komutanlığ 1 emrine verilmesi, ancak bağlı olduğu Müstahkem Mevki Komutanlığı tarafindan kullanılmasıyla kabul edilmişti. Bu birliğin temel amacı Boğaz dışında adalara keşif ve bombardıman yapmak, müttefiklerin Boğaz önündeki faaliyetlerini takip etmekti. Sonradan bu birliğe düşman denizaltılarının Marmara Denizi'ne girmesi, İstanbul Gelibolu deniz ikmal yolunu olumsuz etkilediğinden, gemi trafiğinin güvenlik altına alınması görevi de verilmişti. ${ }^{61}$

1nci Tayyare Bölüğü'ne 13 Temmuz'da 4 adet Rumpler BI tipi silahsız keşif uçaklarının gönderilmesi ardından, Almanya'da eğitimlerini tamamlayan Pilot Üsteğmen Hasan Tahsin Bölük Komutanlığı görevini Alman sivil Pilot Teğmen Pressner'den devralmış, Alman sivil pilotların sayısı da dörde yükselmişti. ${ }^{62}$

18 Temmuz'da düşmanın son durumunu öğrenmek için keşfe çıkan Türk hava birliği, Kefalo koyunda rastladığı Çanakkale Müttefik Kuvvetleri Komutanı Hamilton'un yatına bir uçakla taarruz etmiş, ancak yat isabet almamıştı. ${ }^{63} 28$ Temmuz'da da ay 1şığında Limni Adası'na yapılan hava keşfinde sabah saatlerinde Mondros Koyu'nda 13'ü savaş gemisi olmak üzere 87 gemi tespit edilmiş ve bombalanmıştı. ${ }^{64}$

\footnotetext{
${ }^{59}$ Osmanlı Devri Birinci Dünya Savaşı'nda Türk Harbi, s. 515

${ }^{60}$ Birinci Dünya Harbi Türk Hava Harekatı, s. 48.

${ }^{61}$ Kurter, s.299-300.

62 a.g.e., s. 301.

${ }^{63}$ Birinci Dünya Harbi Türk Hava Harekatı, s. 49-50.

${ }^{64}$ Kayabalı ve Arslanoğlu, s. 97.
} 
Temmuz ayının ortalarında 5 nci Ordu Komutanı Sanders, 1 nci Tayyare Bölüğü'nün kendi karargahının olduğu Gelibolu civarına konuşlandırılmasını istemiş; bu kapsamda Gelibolu civarında hava meydanı olabilecek bir yer aranmış, Galata Köyü güneyinde bugünkü adı Cumalıdere olan bir dere tabanı seçilmişti. Dere tabanı düzeltilerek uçakların iniş kalkış yapabilecekleri bir hale getirilmiş, bölüğün bu yeni meydana taşınması da 21 Temmuz'da tamamlanmıştı.

1 nci Bölüğün uçaklarında telsiz olmamasından dolayı uçaklar topçumuza gözetleme ve ateş tanzimi görevi veremiyordu. Buna karşıllık İngilizler balon gemisini kullanarak başarılı sonuçlar aldığından, sabit balondan yararlanılması gündeme gelmiş, Balkan Savaşları sırasında Edirne Kalesi'nde kullanılan sabit balon onarılarak 21 Temmuz'da Kilyatepe'de konuşlandırılması düşünülmüşse de, düşmanın hava üstünlüğü nedeniyle bundan vazgeçilmiştir. ${ }^{65}$

Bir görüşe göre Gelibolu'ya daha gelişmiş ve birbirinden daha az farklı uçakların oluşturduğu birliklerin gönderilmesi, Çanakkale Boğazı seferinin İttifak kuvvetleri açısından daha başarılı olmasını sağlayabilirdi. Özellikle daha iyi teçhizat ve gereçlerle donatılmış hava filosunun Gelibolu çıkartmalarından önce yeterli fotoğraf keşfi sağlamasına rağmen, psikolojik bombardımanla İstanbul'un paniğe kapılmasına neden olabilirdi. ${ }^{66}$

\section{Anafartalar Çıkarması Süresince Hava Harekatı}

Gelibolu çıkarmalarının başarısızlığı sonrasında İngilizler, Türk Kuvveleri'ni kuzeyden kuşatarak, boğaz için çok önemli olan Kocaçimen ve Conk Tepelerini ele geçirip, Tuzla gölü güneyinde karaya çıkararak Anafartalar üzerinden Kilya Limanı istikametinde kuşatma yapmayı planlıyordu. Müttefiklerin yeni bir çıkarma harekatına girişeceği haberinin alınması ile beraber 28 Temmuz sabahı bir deniz uçağı keşfe başlamış, öncelikle Limni Adası ve Mondros Körfezi keşfedilmiş, burada 87 geminin bulunduğu gözlenmişti. Gemi sayısında eskiye oranla bir azalma, ordugahlarda da küçülme gözlenmişti. Uçak ordugah bölgesine bir bomba attıktan sonra Bozcaada'ya yönelmiş, burada da sadece Fransız uçak birliğinin olduğu görülmüştü.

31 Temmuz gece yarısından sonra 1 nci Tayyare Bölüğü ve Alman Deniz Uçak Birliği'nden iki uçak keşfe çıkmış, Bozcaada'da bir değişiklik olmadığı gözlenmişti. Bu arada Bozcaada havaalanına taarruz yapılmış, 5

\footnotetext{
${ }^{65}$ Kurter, s. 303.

${ }^{66}$ Robin Higham, Hava Gücü Özlü Bir Tarih, Genelkurmay Askeri Tarih ve Stratejik Etüt Başkanlığı Yayınları, Ankara, 1983, s. 42.
} 
bomba ve 500 çivi atılmıştı. Bu taarruz dönüşü, uçaklardan biri hava devriyesine çıkan düşman uçaklarının saldırısına uğramıştı. Ancak Alman Deniz Uçak Birliği'ne ait uçak isabet almasına rağmen üssüne geri dönmüștü. ${ }^{67}$

2 Ağustos'ta Arıburnu'na çıkarma başlamış ve 6 Müttefik uçağı bu çıkarmaya destek vermiştir. Bu çıkarma sırasında düşmanın hava üstünlüğg̈ nedeniyle uçaklarımız keşif uçuşu yapamamış, 3 Ağustos gecesi deniz uçakları İmroz'u keşfedip bombalamış, düşmanın saldırısı karşısında bir uçağımız isabet almıştır. ${ }^{68} 4$ Ağustos'ta Samson Suvla üzerinde son bir keşif uçuşu yapmış ve mıntıka üzerinde hiçbir Türk harekatı olmadığını rapor etmiş, bu arada Tuz Gölü'ne de bomba bırakmıştır. Ancak Samson'un bu eylemi izinsiz olduğu için Hamilton'un tepkisini çekmiş, yine de çamurlu arazide askerlerin yürüyebileceği hatta atlı olarak ilerleyebileceği ortaya çıkmıştı. ${ }^{69}$

Ağustos ayı başında yapılacak büyük taarruza destek amacıyla İngiliz Krallık Donanma Hava Servisi'ne bağlı ikinci uçak grubu da harekat alanına gelmişti. Böylece İngiliz Hava Kuvvetleri 22 uçaklık bir takviye daha almıştı. Bunların yanı sıra bu aşamada İngilizler Çanakkale Cephesi'nde hava gemilerinden de yararlanmıştır. Üç tane SS tipi hava gemisi 2 Ağustos 1915 'te Gökçeada'ya varmış, bunun için bez kaplı bir hangar inşa edilmiş ve hava gemilerinden biri şişirilerek kullanılmaya başlanmıştı. Ancak hava şartları nedeniyle hava gemilerinin sadece denizaltı gözetleme devriyesiyle sınırlı görevleri vardı. Hava şartlarına bağlı konumu ve Osmanlı saldırılarının menzilinde olması nedeniyle Osmanlı uçakları hava gemisi hangarını birkaç kere bombalamış, çok etkili olamayan bu araç Müttefiklerin çekildiği tarihlerde İngiltere'ye geri götürülmüştür. ${ }^{70}$

Ağustos'ta Arıburnu Cephesi'ni tutmuş olan Kuzey grubunun să̆ yanını Suvla Koyu'ndan kuşatmak ve bu grubun gerisinden Marmara'ya ulaşmak amacıyla yapılan ilk İngiliz takviye çıkarması, 6/7 Ağustos'ta Suvla Limanı'na yapılmıştı. Gerçekleşen bu çıkarma sırasında uçaklarımız keşif yapmadığından, düşmanın çıkarma yaptı̆̆ 1 ancak harekat sonrasında anlaşılabilmişti.

Deniz uçaklarının denizaltılarla ilk teması 6 Ağustos'ta olmuş, Marmara Adası'nın batı kıyısı açıklarında bulunan bir düşman denizaltısına bomba taarruzu yapılmış, ancak bir sonuç alınamamıştı. 9 Ağustos günü de bir Gotha WD I Bolayır önlerinde bulunan bir düşman denizaltısına taarruz

\footnotetext{
${ }^{67}$ Kurter, s. 304.

${ }^{68}$ Kansu, Şensöz ve Öztuna, s. 202.

${ }^{69}$ Moorehead, s. 339.

${ }^{70}$ Yilmazer, s. 71.
} 
yapmış, bu taarruzda da denizaltıya bir bomba isabet ettirildiği, bunun sonucu deniz yüzeyinde yağ lekeleri oluştuğu gözlenmişti. Bu nedenle denizaltının batırıldığ kabul edilmiştir. ${ }^{71}$

7 Ağustos'ta Anafarta Muharebeleri başlamış, denizaltı tehlikesine karşı deniz uçaklarımıza Marmara'da keşif görevi verilmiştir. Bu uçakların seyir sahasını arttırmak için Tekirdağ'da ve Marmara'da Ekinlik adasına yardımcı iniş yeri hazırlanmış, benzin ikmal depoları kurulmuştur. ${ }^{72}$

9 Ağustos'ta yeniden çarpışmaların başlaması sonrasında İngilizlerin ileriye gitmeleriyle bir harekat savaşı gelişmiş, iki Türk Tümeni tepeli araziye tırmanan İngilizleri ovaya geri püskürtmüştü. Muharebeden sonra İngilizler 8 ve 9 Ağustos'ta karaya çıkan yeni kuvvetleri ileri sürmüş, ancak Türk direnişi sayesinde Kireçtepe elde kalmıştı. ${ }^{73}$

6 Ağustos'ta başlayarak 10 Ağustos'a kadar devam eden İngiliz ve Anzak güçlerinin katıldığı harekatta Osmanlı 5 nci Ordusu'na bağlı hava birlikleri harekat boyunca keşif yapmanın yanı sıra, düşman hattının bombardıman saldırılarını da gerçekleştirmiştir. İngilizler Anafartalar savaşı öncesinde yeni harekatın yerinin belirlenmemesi için Gökçeada'dan kalkan uçakların yüksekten uçmasını ve yerlerinde çok durmamaları talimatını vermişti. Ağustos ayı içerisinde 1 nci Bölük 5 nci Ordu'ya yoğun destek sağlamış, attı̆̆ bombalarla bir düşman gemisini batırmış ve 4 uçakla dört gün devam eden muharebelerde 51 saat muharebe uçuşu yapmıştır. ${ }^{74}$

12 Ağustos'ta iki Short deniz uçağı Gelibolu'nun kuzeyinde bir buharlı gemi keşfetmiş ve bu hedefe torpido saldırısı için hazırlanmıştı. Bu uçaklardan birinin arızalanması sonucu Pilot K. Edmons, kontrolündeki 842 numaralı bir Short uçağı ile yaklaşık 700 metre mesafeden ve suya 5 metre yüksekten torpidoyu salmıştır. Edmonds torpidonun hedef istikametini gördükten sonra ana gemisi Ben My Chree'ye geri dönmüş, bu olay dünya havacılık tarihinde ilk havadan torpido saldırısı olarak yerini almıştır.

Binbaşı Edmons'un torpido taarruzları bundan sonra da devam etmiş, 19 Ağustos'ta bir diğer uçuşunda Akbaş iskelesine doğru seyretmekte olan 3 gemiden birine taarruz ederek bir gemide yangın çıkarmıştır. Aynı gün Teğmen GB Dacre idaresindeki bir Short 184'de bir gemiye taarruz ederek torpido bırakmış, İngiliz kaynaklarına göre bu gemi de batırılmıştır. ${ }^{76}$

\footnotetext{
${ }^{71}$ Kurter, s. 309.

${ }^{72}$ Kansu, Şensöz ve Öztuna, s. 202.

${ }^{73}$ Carl Mühlman, Çanakkale Savaşı, Timaș Yayınları, İstanbul, 1998, s. 130-131.

${ }^{74}$ Kansu, Şensöz ve Öztuna, s. 202, Kurter, s. 309.

${ }^{75}$ Yilmazer, s. 95, Kurter, s. 309.

${ }^{76}$ Kurter, s. 309.
} 
Anafartalar muharebeleri tüm şiddetiyle devam ederken Türk tarafinın en kısa deniz yolu Gelibolu Yarımadası ve İstanbul, Marmara limanları arasında olduğu için 5 nci Ordu'nun tüm ihtiyaçlarının buradan karşılanmasına çalışılmış, ancak düşman denizaltılarıyla mücadele etmek amacıyla Müstahkem Mevki Komutanlığı'na destek verilmesi istenmiştir. Ancak Komutanlık verdiği cevabında elde iki deniz uçağı olduğunu, bunlardan birinin; kalenin deniz keşifleri için kullanıldığını, diğerinin de uçamaz durumda olduğu gerekçesiyle bu isteği reddetmiştir. Bu cevap sonrasında durumun öneminin anlaşılmasıyla Mevki Komutanlığı kalan tek uçağı Marmara'da dolaşan düşman denizaltılarını keşif, gözetleme ve bombalama için tahsis etmişti. ${ }^{77}$

Çanakkale'de birbiriyle savaşan tarafların havada daha sık karşılaşması üzerine silahlı Albatros C tipi uçaklar Ağustos ayından itibaren Yeşilköy’e gelmeye başlamıştı. Bu uçaklarda rasıt, görüş alanı kanatlar ve dikmelerle kısıtlanmamış olan arka tarafta oturuyordu. Dairesel olarak her yöne dönebilen bir çember üzerindeki makineli tüfekle geriye ve yanlara doğru hem savunma hem de taarruz imkanı sağlanıyordu. Böylece Ağustos ve Eylül ayında 1 nci Tayyare Bölüğ̈̈'nün elindeki uçaklar artmış, yeni gelen havacılarla da etkinlik yükselmiştir. Hatta 27 Eylül 1915'te Alman Üsteğmen Karl Kettembeil Çanakkale Cephesi'nde düşman uçağını düşüren ilk rasıt olmuştu. Böylece ilk kez bir Türk uçağı Müttefik uçağını Çanakkale Cephesi'nde düşürmüştür. ${ }^{78}$

Çanakkale Savaşları konusunda önemli belge eserlerden birini hazırlamış olan Alan Moorehead Ağustos uçuşları sonrasında ilginç bir anekdotu da belirtmektedir. Buna göre Müttefiklerin hava gücü komutanı Samson alçaktan bir uçuş sırasında bir Türk kurmay arabasını fark etmiş ve araca iki bomba atmıştır. Bu saldırıda arabada bulunan Mustafa Kemal Paşa sağ olarak kurtulurken, araç sürücüsü hayatını kaybetmiştir. ${ }^{79}$

5 Eylül'de 1 nci Bölük uçakları cephe üzerinde keşfe çıkmış, Tuz Gölü civarında 70 çadırlık yeni bir Müttefik Ordugahı keşfedilmişti. Bu dönemde gelen istihbaratlardan, Müttefiklerin yeni bir harekat için 50 bin kişilik kuvvet hazırladığ1, bu kuvvetin sevk yönünün de Midilli olduğu mesajı alınmıştı. Bu nedenle Midilli'ye yapılacak bir keşif önem kazanmıştı. 6 Eylül keşfinde ise Bozcaada ve Midilli de bir değişim görülmemişti. Aynı gün İmroz keşfinde ve 10-11 Eylül'de Bozcaada ve Midilli'ye tekrarlanan keşif uçuşlarında da bölgede yeni bir durum değişikliğine rastlanmamıştır.

\footnotetext{
${ }^{77}$ Birinci Dünya Harbi Türk Hava Harekatı, s. 51.

${ }^{78}$ Yilmazer, s. 99.

${ }^{79}$ Moorehead, s. 443.
} 
18 Eylül'de deniz uçakları Marmara'ya kara uçakları Midilli'ye keşif uçuşları gerçekleştirmişler, bunun ardından Bölük Komutanı Yüzbaşı Körner yaptığı bir kara keşfinde Gelibolu'daki kuvvetlerde bir azalma olduğunu rapor etmiştir. 27 Eylül'de ise Teğmen Pressner ve Kettembeil ilk kez bir Müttefik uçağını hava muharebesinde düşürmüştür. ${ }^{80}$

Bu dönemde Ian Hamilton'un anılarından da öğrendiğimiz üzere Türk uçakları sadece keşif hizmetinde kullanılmamış, düşman karargahlarının bombalanması görevini de yürütmüş̧ür. Buna göre 16 Eylül'de bir uçağımız sabah saatlerinde havalanarak Hamilton'un da bulunduğu karargaha dört bomba isabet ettirmiş, bu eylem 19 Eylül, 27 Eylül ve 28 Eylül gecelerinde de tekrarlanmıştır. ${ }^{8}$

20 Eylül'de Limni, Bozcaada, Midilli, İmroz, Saroz Körfezi üzerinde gerçekleştirilen hava keşiflerinde adalarda düşman kuvvetlerinin azaldığ 1 tespit edilmişti. Keşifler sırasında taarruz görevi de yürütülmüş, özellikle sabit balonun etkisiz hale getirilmesi amaciyla 27 Eylül'de 1 nci Tayyare Bölüğü'ne ait av uçaklarıyla balon tesisine bomba isabet ettirilmişse de, hasarın ne ölçüde olduğu tespit edilememiştir. ${ }^{82}$

\section{Sonuç}

1914 yılında I. Dünya Savaşı'nın başlamasıyla İtilaf Devletleri'nin Çanakkale Boğazı'nı savaş gemileriyle geçmek ve böylece İstanbul'a kavuşma isteklerini gerçekleştirmek amacıyla açtıkları Çanakkale Cephesi, tarafların karada ve denizde olduğu gibi havada da karşılaşmaları nedeniyle dünya havacılık tarihinin önemli savaşlarından biri olmuştur. Müttefiklerin kesin yenilgisi ile sonuçlanan Çanakkale Savaşları'nda Türk havacıları; zaferin kazanılmasında önemli görevler üstlenmişler, az sayıda uçak ve yetersiz ekipmanla gerçekleştirdikleri keşif, taarruz ve muhabere görevlerinde büyük başarılar sağlamışlar, savaşın seyrine olumlu katkı yapan hizmetlerinin dışında, modern Türk askeri havacılığının gelişmesi konusunda da etkili olmuşlardır.

Çanakkale'de deniz ve kara savaşlarının sürdüğü aylar boyunca müttefik kuvvetlerinin 40 civarında uçağı karşısında az sayıda Türk uçağı ve havacısı görev yapmasına rağmen önemli başarılara imza atılmıştır. $\mathrm{Bu}$ dönemde 1 nci Tayyare Bölüğü'nde 5'i pilot ve 10'u rasit olmak üzere toplam 15 Türk havacı ve 23 Alman havacı görev yapmıştır. Deniz ve hava

\footnotetext{
${ }^{80}$ Kurter, s. 311, Ünalp, s. 137.

${ }^{81}$ Ian Hamilton, Çanakkale Günlüğü, (çev. Osman Öndeş), Hürriyet Yayınları, İstanbul, 1972, s. 262- 268

${ }^{82}$ Birinci Dünya Harbi Türk Hava Harekatı, s. 53.
} 
savaşları boyunca 6'sı hava savaşı, 16'sı ise yerden açılan savunma ateşi sonucunda teyit edilmiş toplam 22 düşman uçağı düşürüldüğü de kabul edilmektedir. Bunun dışında Türk havacılardan hiçbiri Çanakkale Savaşları sırasında hayatını kaybetmemiştir.

Savaşın başlaması ile beraber, 18 Mart saldırıları öncesi taraflar keşif çalışmalarına ağırlık vermiş, İngilizler bu devrede Türk savunma hatlarını da bombalamıştır. Karşı tarafin stratejilerini belirleme amacıyla yapılan keşif uçuşları ile düşmanın elindeki silah tipleri ve asker miktarı gibi bilgiler ilgililere aktarılmıştı.

Çanakkale Savaşları'nda askeri havacılık alanında birçok ilk yaşanmıştır. Öncelikli olarak Çanakkale Savaşları tarihte kara, deniz ve hava unsurlarının beraber kullanıldığı ilk amfibi harekat olması bakımından önemli olmuştur. Çanakkale Savaşları'nda Türk havacıların imza attıkları bir başka başarı da çağımızda vazgeçilmez olan elektronik karıştırmayı ilk kez bu savaşta kullanmaları olmuştur. 1915'te İngiltere'nin en önemli savaş gemilerinden olan Queen Elizabeth'in konuyla ilgili belgelerinde, bir Türk savaş uçağ1 yüzünden telsiz haberleşmesinde güçlük yaşadıklarının rapor edilmesi de bunu doğrulamıştır. Aynı zamanda ilk kez Çanakkale Cephesi'nde uçaklar ile denizaltıların işbirliğinin görülmesi ve İngiliz uçaklarının torpido atarak bir Türk muhribine yaptığı saldırının torpido uçaklarının doğması ve gelişmesine zemin hazırlaması da Çanakkale Cephesi'nde yapılan hava savaşlarının önemini bir kez daha ortaya koymaktadır.

Türk askeri havacılık tarihi açısından da Çanakkale Cephesi'nde birçok ilk yaşanmıştır. İlk kez Çanakkale Cephesi'nde havadaki bir Türk uçağ 1 düşman uçağını makineli tüfek atışıyla düşürmeyi başarmıştır. Böylece Üsteğmen Ali Rıza Bey idaresindeki Albatros C I tipi uçakta Rasıt Teğmen İbrahim Orhan, bir düşman uçağını düşüren ilk Türk olarak tarihe geçmiştir. Türk havacılarının bu buluşlarını daha sonra Almanlar da kendi uçaklarında uygulamışlar ve bu uçaklardaki rasıt yerine makineli tüfek yerleştirmişlerdir. Yine bu dönemde güney cephedeki karşı taarruzları desteklemek amacıyla düşman çıkarma gemileri ve ordugahının bombalanması ve Manica balon gemisine taarruzlar yapılarak, geminin balonunu toplayıp görev yerinden ayrılması sağlanmış, yani bir bakıma Çanakkale semalarında yakın hava desteğinin basit bir uygulama örneği yaşanmıştır. Sonuç olarak Çanakkale Cephesi'nde hava savaşlarında yaşanan havacılık deneyimlerinin, tarafların sonraki yıllarda askeri havacılık alanında gerçekleştirdikleri ilerlemelere temel teşkil ettiğini de belirtmek gerekir. 


\section{Kaynakça}

Alasya, Fikret, “Türklerde Havacılık”, Türk Kültürü, Sayı: 34, Ağustos 1965

Anadol, Cemal, Türk Havacılık Tarihi, İstanbul, 1990

Artuç, İbrahim, 1915 Çanakkale Savaşı, Kastaş Yayınları, İstanbul, 2004

Bayrak, M. Orhan; Çanakkale Savaşları, Bir Harf Yayınları, İstanbul, 2005

Birinci Dünya Harbinde Çanakkale Cephesi; V. Cilt, 2. Kitap, Genelkurmay Harp Tarihi Başkanlığı Harp Tarihi Yayınları, Seri No. 3, Genelkurmay Basimevi, Ankara, 1978

Birinci Dünya Harbi Türk Hava Harekatı; IX. Cilt, Genelkurmay Harp Tarihi Başkanlığı Resmi Yayınları, Seri No: 3, Genelkurmay Basımevi, Ankara, 1969

Birinci Dünya Harbi’nde Türk Harbi: Çanakkale Cephesi Harekatı (Haziran 1914-24 Nisan 1915), V. Cilt, 1. Kitap, Genelkurmay Basımevi, Ankara, 1993

Hamılton, Ian, Çanakkale Günlüğü; çev. Osman Öndeş, Hürriyet Yayınları, İstanbul, 1972

Hıgham, Robin, Hava Gücü Özlü Bir Tarih, Genelkurmay Askeri Tarih ve Stratejik Etüt Başkanlığı Yayınları, Ankara, 1983

Kansu, Yavuz, ŞENSÖZ, Sermet, ÖZTUNA, Yılmaz, Havacılık Tarihinde Türkler, Hava Kuvvetleri Basım ve Neşriyat Müdürlüğü, Ankara, 1971

Kayabalı, İsmail, ARSLANOĞLU, Cemender, Çanakkale Zaferi 1915, Ankara, 1975

Keyüsk, Mazlum, Türk Havacılık Tarihi: 1912-1918, Uçuş Okulları Basımevi, Eskişehir, 1950

Kurter, Ajun, Türk Hava Kuvvetleri Tarihi, Ankara, 2002

Moorehead, Alan, Çanakkale Geçilmez: Gallipoli, çev: Günay Salman, Milliyet Yayınevi, İstanbul, 1972

Mühlman, Carl, Çanakkale Savaşı, Timaş Yayınları, İstanbul, 1998

Mütercimler, Erol, Bu Vatan Böyle Kurtuldu, 4. Baskı, Alfa Yayınevi, İstanbul, 2005

Türk Silahlı Kuvvetleri Tarihi Osmanlı Devri Birinci Dünya Savaşında Türk Harbi, Çanakkale Cephesi Harekatı (Haziran 1915 - Ocak 1916); V. Cilt, 3'ncü Kitap, Türk Silahlı Kuvvetleri Tarihi, Genelkurmay Askeri Tarih ve Stratejik Etüt Başkanlığı Tarih Yayınları, Seri No:3, Genelkurmay Basımevi, Ankara, 1980

Ünalp, Rezzan, "Turkish Air Operations During the Dardanelles Campaign", Communiqués the Joint Turkish - Israeli Military Conference I ( 9-12 April 2000 İstanbul); Genelkurmay Askeri Tarih ve Stratejik Etüt Başkanlığ Yayınları, Genelkurmay Basımevi, Ankara, 2000

Whistler, Richard, "Over the Wine Dark Sea: Aerial Aspects of the Dardanelles, Gallipoli Campaign, Part III, Turco-German Aviation", Over the Front, Volume: 9, No: 3, 1994

Yılmazer, Bülent, Çanakkale Hava Savaşları, Mönch Türkiye Yayıncılık, Ankara, 2005 